\title{
EHEA INTERNATIONAL STUDENTS MOBILITY AND TRANSPARENCY
}

\author{
Tijmen Weber ${ }^{1}$, Florentin Popescu ${ }^{1}, \&$ Roman Iskandaryan ${ }^{2}$ \\ ${ }^{1}$ HAN University of Applied Sciences, Ruitenberglaan 31, 6826 CC, Arnhem (The Netherlands) \\ ${ }^{2}$ Plekhanov Russian University of Economics, Stremyannyy Pereulok, 36, Moscow (Russia)
}

\begin{abstract}
This paper investigates the importance of transparency of internationalization and various obstacle and barriers that influence international student mobility within the European Higher Education Area (EHEA). Having in mind that due to privacy regulations and availability of data regarding international student mobility, this article is using a framework based on literature review as well as using data made available by Eurostat. The authors analyze patterns in international student mobility, both between countries and over time, using various literature quantitative analyses based on survey data to underline that internationalization and various factors are relevant and can positively influence the international student mobility. Even though transparency is thought of as one of the benefits of European Higher Education Area (EHEA), it has evolved into an essential component of the European Union's strategy for bringing higher education frameworks up to date; students, employers and policy maker must have a greater degree of transparency in order for them to better fill out their roles and achieve their objectives. Higher education management also greatly gains from transparency, since it supplies important data in the process of coming up with new strategies and making decisions. This article presents an important contribution to this growing field of literature by doing a comparative analysis about the factors which positively improve the international student's mobility within the EHEA. The three folded impact of this paper is obvious for the stakeholders mentioned as students, institutions and policy makers are responsible for the smooth cooperation and coordination for a better international mobility.
\end{abstract}

Keywords: European Higher Education Area (EHEA), student's mobility, international higher education, internationalization.

\section{Introduction}

The key for the legitimacy, competitiveness and funding for the higher education institutions and their subunits is represented by the unfailing information regarding the benefits provided to their funders, students and society overall. The transparency of higher education institutions has an important role in the quality of accountability and decision-making process. Consequently, transparency of the benefits provided by higher education institutions should be an essential pillar for the governance framework. Due to the increasing variety of these benefits, students have to face an important challenge to decide what field of study to choose and where to study. Moreover, governments are interested that the research services and quality education that are important to the communities, local business and labor market to be offered by the higher education institutions that are in their jurisdiction.

All the stakeholders that are interested in the higher education are expecting transparency. The demand for transparency in higher education is growing from the side of the general public, public authorities and of course from the side of students. Tools that are helpful for a broader use of information and for a better understanding of the performances and services provided by the higher education institutions are needed. A core objective of the rethinking governance in higher education is the improvement of the transparency regarding the activities and outcomes provided by the higher education institutions.

In the article Transparency in Higher Education: The Emergence of a New Perspective on Higher Education Governance, the authors critically discuss some transparency tools such as accreditation, rankings and performance contracts according to a larger context of higher education policy-making and governance. These transparency tools are analyzed from the perspective of how they are modified in order to ensure the growing demand for transparency in higher education (Jongbloed et al. 2018). According to Schwaninger et al. (2017) higher education institutions have their own capacity 
to lead into a collective environment and they act into a multi-centric network. Students and other stakeholders must be protected and supported by the government against rent-seeking behavior and different similar perverse effects. Information asymmetry between higher education providers and students, government and other stakeholders is acknowledged and intended to be rectified by the orientation in the networked governance paradigm and by encouraging transparency. One of the core characteristics of networked management is given by the sharing information by using ICT tools like ranking websites. Stakeholders can behave more effectively and efficiently in the network based on the trust that increased with the information shared. In order to increase the public value of higher education in the following years it is essential to improve the transparency tools since transparency is one of the fundamental elements of the dynamic in the networked management of higher education systems. What is the scope of higher education policies to attract international students if they are not transparent? What is the scope of specific international mobility policies to attract international students if they are not transparent? What is the scope of higher education institutions to attract international students if they are not transparent? Consequently, even if accessing the data is quite impossible due to the privacy issues, students' perspective is decisive for transparency.

\section{Internationalization and international student mobility}

In order to gain a better understanding of the value of internationalization and to increase the interest in mobility a great tool can be internationalization at home. The demands related to the number and accessibility of outgoing mobility programs should never be reduced by the internationalization at home tools. There are still many barriers that remain mostly unsolved despite the fact that the need for equitable access to mobility has known for a long time now. The courses taught in English or in different foreign languages and the mobility of professors and lecturers represent the foundation of the concept of internationalization at home. However, the degree of use of this concept varies around the world. Both local and international students who are involved in internationalization experience are integrated worryingly uncommon.

The number of international students coming from outside of Europe and the European Union increase and this situation will be a challenge especially regarding visas for the European higher education institutions. According to ICEF (2018), India and China are those two countries that account for about $40 \%$ of the students that are part of the outgoing mobility between the years of 2012 and 2015 . Moreover, these two countries have almost half of the tertiary-education-aged population at the global level.

More focus should be paid to modernize, updating and equalizing visa policies in European countries, moreover now considering the imminent Brexit. This focus should be centered to those students who are facing higher costs and most difficulties when applying for visas in European countries, namely non-European international students. One of the major troubles for some non-European international students is represented by the length of student visas. These non-European international students must re-apply for visas every year in order to avoid the risk of deportation before completing a full degree as an international student and this situation is a well-known barrier.

Even if the participation of international students enriches the education, it should be emphasized that in situations of unclear future prospects internationalization cannot flourish. All the European HEIs should consider international students as an opportunity and not as potential cash-cows. In order to support this idea, the needs of students should be seen as highly significant in international mobility. Internationalization should be a core topic in Europe in order to reach set goals. In this context, internationalization and mobility in Europe should be a priority where students must be an essential part of internationalization strategies that require special attention. International students must be integrated in the local student body. Moreover, very often internationalization is not encouraged due to the numerous obstacles that international students have to face during the mobility. Longstanding efforts in the internationalization area may be compromised as a consequence of the unresolved long-term problems and negative experiences that students may have during the mobility. In order to ensure sufficient opportunities to work for students that choose mobility in a country, visa periods should stand during the entire period of stay in a country, consequently, the governments should consider students as a crucial stakeholder when visa regulations are created and updated at national and international level.

\section{International student mobility obstacle and barriers}

In the different phases of the decision process, different obstacles may deter students from studying abroad. Financial and familial obstacles are of especially high relevance with regard to the initial decision to go abroad for study purposes. Students who are already planning to study abroad are more 
concerned about practical matters: integrating a stay abroad into their study programme, getting relevant information, securing a place in a mobility programme, and ensuring their results achieved abroad will be recognized.

Table 1 shows an overview of what students perceive to be obstacles preventing them from studying abroad. All the studies were based on quantitative analyses using survey data. The obstacles were split into eight dimensions based on what was most commonly assess in the literature. Every $\mathrm{x}$ in the table means that it was found by a study. If there is no $\mathrm{x}$ it means that either it was not measured, it was not found to be significant, or the authors indicated that it was not important in their results.

Financial cost refers simply the financial costs that students would incur if they would decide to study abroad. The social cost refers more specifically to leaving behind friends and family and the anxiety that is involved in forming new networks. Lack of information relates to students indicating that they are not sufficiently informed to feel comfortable in deciding to study abroad. Lack of foreign language skills concerns student's fear that their language proficiency is not good enough for staying abroad for a longer period of time. Institutional problems are related to obstacles concerning the higher education institutions such as the transfer of credits or the recognition of foreign degrees. Uncertainty about benefits concerns students that indicate that they are unsure about whether studying abroad is beneficial for their career or personal development. Academic performance is related to student's grades or their doubts about their academic performance. Finally, lack of motivation is a general concept where students simply indicated that they did not feel motivated to study abroad without being more specific.

Table 1. Indicators mentioned as important.

\begin{tabular}{|c|c|c|c|c|c|c|c|c|}
\hline & $\begin{array}{l}\text { Financial } \\
\text { cost }\end{array}$ & $\begin{array}{l}\text { Social } \\
\text { cost }\end{array}$ & $\begin{array}{l}\text { Lack of } \\
\text { information }\end{array}$ & \begin{tabular}{|l|} 
Lack of \\
foreign \\
language \\
skills \\
\end{tabular} & $\begin{array}{l}\text { Institutional } \\
\text { Problems }\end{array}$ & $\begin{array}{l}\text { Uncertainty } \\
\text { about } \\
\text { benefits }\end{array}$ & $\begin{array}{l}\text { Academic } \\
\text { performance }\end{array}$ & $\begin{array}{l}\text { Lack of } \\
\text { Motivation }\end{array}$ \\
\hline $\begin{array}{l}\text { Beerkens, } \\
\text { Souto-Otero, } \\
\text { de Wit and } \\
\text { Huisman } \\
(2015)\end{array}$ & $x$ & $\mathrm{x}$ & $\mathrm{x}$ & $\mathrm{x}$ & $\mathrm{x}$ & $\mathrm{x}$ & & $\mathrm{x}$ \\
\hline $\begin{array}{l}\text { Bryya and } \\
\text { Ciabiada } \\
(2015)\end{array}$ & $\mathrm{x}$ & $\mathrm{x}$ & $\mathrm{x}$ & & & & & $\mathrm{x}$ \\
\hline $\begin{array}{l}\text { Doyle et al } \\
(2010)\end{array}$ & $\mathrm{x}$ & $\mathrm{x}$ & $\mathrm{x}$ & & $\mathrm{x}$ & & $\mathrm{x}$ & \\
\hline $\begin{array}{l}\text { Hauschildt } \\
\text { (2016) }\end{array}$ & $x$ & $\mathrm{x}$ & $\mathrm{x}$ & $x$ & $\mathrm{x}$ & & & $\mathrm{x}$ \\
\hline $\begin{array}{l}\text { Kmiotek- } \\
\text { Meier et al } \\
(2019)\end{array}$ & $\mathrm{x}$ & & $\mathrm{x}$ & $\mathrm{x}$ & $\mathrm{x}$ & & & \\
\hline $\begin{array}{l}\text { Lörz, Net } \\
\text { zand Quast } \\
\text { (2016) }\end{array}$ & $\mathrm{x}$ & $\mathrm{x}$ & & $\mathrm{x}$ & & $\mathrm{x}$ & $\mathrm{x}$ & \\
\hline Netz (2015) & $\mathrm{x}$ & $\mathrm{x}$ & & $\mathrm{x}$ & & $\mathrm{x}$ & $\mathrm{x}$ & \\
\hline $\begin{array}{l}\text { Souto-Otero, } \\
\text { Huisman, } \\
\text { Beerkens, de } \\
\text { Wit and } \\
\text { Vujic (2013) }\end{array}$ & $\mathrm{x}$ & $\mathrm{x}$ & $\mathrm{x}$ & $x$ & $\mathrm{x}$ & $\mathrm{x}$ & & \\
\hline
\end{tabular}

From table 1 it can be seen that financial cost is the most often cited obstacle. Moving abroad is costly and while grants are available, many students see them as insufficient. Especially the ERASMUS grant is considered by some to be too low to appropriately cover the costs (Souto-Otero et al., 2013). The second most cited obstacle is the social cost which is not too surprising since moving abroad means leaving behind family, friends and partners. Lack of information is more surprising since it would be expected that this is relatively easily remedied by students themselves. Like lack of information, lack of foreign language skills was mentioned by six out of eight studies. Institutional problems come in sixth place showing that students apparently are unsure about the ability of higher education institutions to coordinate and communicate. Uncertainty about the potential benefits was only reported by half of the studies, and academic performance and lack of motivation only by three studies. Some studies also looked at difference between countries (e.g. Netz, 2015; Beerkens et al., 2015) but found these differences to not be very substantial indicating that obstacles and barriers are largely similar across different contexts. 
These findings can be interpreted in line with the conceptualization by Beech (2015). She argues that the decision to move abroad is not simply due to financial resources, many international students come from a background in which studying abroad is normalized and accepted as a natural step in one's career. Coming from such a culture could lower the social cost and increase the perceived benefits of spending some time studying abroad. This would therefore mean that studying abroad is not just a question of resources but also of attitude and culture.

\section{Conclusions and further research}

The question regarding the positive assessment of increasing internationality arises and if this positive assessment has continued. Despite the fact that numerous advantages were highlighted for those countries losing talent by "brain circulation", there were also critiques regarding this situation. The negative impact of the "brain drain" process has been stressed out from several decades ago (see Wächter, 2006). There are different views regarding internationalization and its consequences, even if there is no dominant policy or a certain perspective that can be claimed. There are fears considering that quality and undermining academic approaches through economic rationales are effects of internationality. Moreover, it is considered that aspects such as "global citizenship" and "international understanding" have lost their role as fundamental values of internationality of higher education.

Financial situation is so far the major and most dominant obstacle for the students interested in outgoing mobility. For over a decade financial aspect has been a major obstacle to mobility and it still remains unsolved in many situations. Statistical data and also some research papers, as for example Ballatore \& Ferede (2013), point out that most of the students who are applying for Erasmus+ mobility are mostly part of distinct higher socioeconomic groups. Such studies are focused on the elitist nature of different mobility programs and also on the impact that these programs produce. According to Ballatore \& Ferede (2013) there is an impression that international mobility is more accessible for certain type of students, in this way creating privilege among students. This observation is based on the fact that those students who have been part of international mobility are mostly students having a higher income and also more job opportunities. Another research elaborated in Germany by Netz \& Grüttner (2018) comes to support this view. The empirical study developed by Netz \& Grüttner (2018) highlights the fact that nowadays there is a tendency in mobility programs to generate a division between students having a lower socioeconomic background with those students having a higher socioeconomic background even more deeply.

This deepening inequality needs immediate attention since it is not in accordance with the objectives and values of European mobility programs. There is a direct contradiction between this deepening of separation among students coming from different socioeconomic backgrounds and the engagements taken at the Yerevan communiqué in 2015. According to the Yerevan Communiqué (2015) the EHEA will follow certain steps in order to ensure that the gender balance will be improved, the social dimensions of higher education will be intensified and opportunities for access and completion of international mobility will be expanded even for those students having disadvantaged backgrounds.

Until the inevitable disparities that are present within the actual system(s) are not solved, the full potential of mobility cannot be reached even if mobility is a tool helpful for the improvement of the learning and abilities of all learners. The number of dependents, the lower income and several other economic factors are among the obstacles that are part of the internationalization process.

\section{References}

Ballatore, M. \& Ferede, M. K. (2013). The Erasmus Programme in France, Italy and the United Kingdom: student mobility as a signal of distinction and privilege. European Educational Research Journal, 12(4), 525-533.

Beech, S. E. (2015). International student mobility: The role of social networks. Social \& Cultural Geography, 16(3), 332-350.

Beerkens, M., Souto-Otero, M., de Wit, H., \& Huisman, J. (2016). Similar students and different countries? An analysis of the barriers and drivers for Erasmus participation in seven countries. Journal of Studies in International Education, 20(2), 184-204.

Bryła, P., \& Ciabiada, B. (2014). Obstacles to international student mobility: the case of Poland. Trends Journal of Sciences Research), 1(1), 12-16.

Doyle, S., Gendall, P., Meyer, L. H., Hoek, J., Tait, C., McKenzie, L., \& Loorparg, A. (2010). An investigation of factors associated with student participation in study abroad. Journal of Studies in International Education, 14(5), 471-490. 
Hauschildt, K. (2016). What are the obstacles to student mobility during the decision and planning phase? Retrieved from: http://ecsta. org/wpcontent/uploads/2016/07/EV_IB_mobility_obstacles. pdf

ICEF monitor (2018). New study forecasts slowing growth in international student mobility. Retrieved from http://monitor.icef.com/2018/02/new-study-forecasts-slowing-growth-in-internationalstudent-mobility/

Jongbloed, B. W. A., Vossensteyn, H. J. J., van Vught, F., \& Westerheijden, D. F. (2018). Transparency in Higher Education: The Emergence of a New Perspective on Higher Education Governance. In A. Curaj, L. Deca, \& R. Pricopie (Eds.), European Higher Education Area: The Impact of Past and Future Policies (pp. 441-454). Springer, https://doi.org/10.1007/978-3-319-77407-7 27

Kmiotek-Meier, E. A., Skrobanek, J., Nienaber, B., Vysotskaya, V., Samuk, S., Ardic, T., \& Schlimbach, T. (2019). Why is it so hard? And for whom? Obstacles to intra-European mobility. Migration Letters.

Lörz, M., Netz, N., \& Quast, H. (2016). Why do students from underprivileged families less often intend to study abroad? Higher Education, 72(2), 153-174.

Netz, N. \& Grüttner, M. (2018, March). Does international student mobility increase social inequality? Evidence from the German labour market. Presentation from EUROSTUDENT VI Final Conference, Hotel Aquino, Berlin.

Netz, N. (2015). What deters students from studying abroad? Evidence from four European countries and its implications for higher education policy. (2), 151-174.

Schwaninger, M., Neuhofer, S., \& Kittel, B. (2017). Contributions of experimental research to network governance. In B. Hollstein, W. Matiaske, \& K.-U. Schnapp (Eds.), Networked governance: New research perspectives (pp. 189-209). Dordrecht etc.: Springer

Souto-Otero, M., Huisman, J., Beerkens, M., De Wit, H., \& Vujić, S. (2013). Barriers to international student mobility: Evidence from the Erasmus program. Educational Researcher, 42(2), 70-77.

Wächter, B. (2006). Brain drain: what we know and what we do not know. In Teichler, U. (ed.). The Formative Years of Scholars. London: Portland Press, 51-66

Yerevan Communiqué. (2015). Yerevan Communiqué, Yerevan, 14-15 May. Retrieved from http://bologna-yerevan2015.ehea.info/files/YerevanCommuniqueFinal.pdf 